\title{
ФАКТОРИ ПРОГРЕСУВАННЯ АВТОІМУННОГО ТИРЕОЇДИТУ У ОСІБ МОЛОДОГО ВІКУ З ГАСТРОЕЗОФАГЕАЛЬНОЮ РЕФЛЮКСНОЮ ХВОРОБОЮ: РОЛЬ СИСТЕМИ ДЕТОКСИКАЦІЇ КСЕНОБІОТИКІВ, МЕХАНІЗМІВ ЕНДОГЕННОГО КОНТРОЛЮ ТА СТИМУЛЯЦІї
}

\author{
Пасіешвілі Т. М., Ковальова О. М., Пасіешвілі Л. М., Железнякова Н. М. \\ Харківський національний медичний університет, м. Харків, Украйна \\ pasotoma2017@gmail.com
}

Будь яка зустріч патогену з організмом паціента супроводжуеться комплексом захисних реакцій, виразність, послідовність і об'єм яких залежить від властивостей інфекту, що його викликав. Серед таких комплексних реакцій розглядають окислювальний стрес, поняття якого було запропоновано Bulger \& Helton (1998) і характеризувало стан, при якому токсичні активні форми кисню долають ендогенний антиоксидантний захист господаря. При окислювальному стресі відбувається надлишкове накопичення вільних радикалів, які реагують зі складовими клітинних мембран, внаслідок чого спостерігається ушкодження клітин i, таким чином, порушення функції органів [1]. До чотирьохрівневого складу антиоксидантної системи (АОC) входять ферментні та неферментні сполу- ки, які приймають участь у розвитку гострих і хронічних патологічних станів [2]. Основними антиоксидантами організму е глутатіони, система яких включае декілька ферментів, що забезпечують контроль внутрішньоклітинного мікросередовища, необхідного для нормального функціонування клітин [3].

Система антиоксидантного захисту (АОЗ) забезпечуе утилізацію "відпрацьованого матеріалу» клітинних мембран і контролюе фізіологічний апоптоз [4]. Розвиток запалення посилюе роботу системи, що дозволяе контролювати не тільки фізіологічний, але й патологічний апоптоз [5]. При цьому активація АОС відбуваеться не тільки внаслідок розвитку патології, але й залучення внутрішніх резервів. Окрім активного включення системи глутатіонів, до процесу

* Роботу виконано в межах планової наукової тематики Харківського національного медичного університету «Механізми формування гастроезофагеальної рефлюксної хвороби із супутньою патологією та роз-

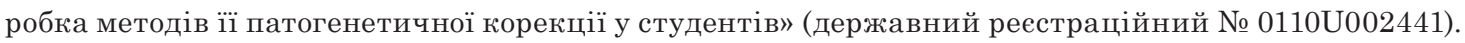

Установою, що фінансуе дослідження, е МОЗ України.

Автори гарантують повну відповідальність за все, що опубліковано в статті.

Автори гарантують відсутність конфлікту інтересів і власної фінансової зацікавленості при виконанні роботи та написанні статті.

Рукопис надійшов до редакції 12.08.2020. 
захисту від активних фрорм кисню залучаються супероксиддисмутази (СОД), які містять метали [6, 7]. Так, активний запальний процес на другому етапі роботи АОC може призводити до збільшення синтезу мітохондриальної Mn-залежної СОД (СОД2). Посилення її синтезу пов'язують не тільки зі збільшенням активності системи, але й дією антивікового білку Клото, одним із ефектів якого є стимуляція АОС [8].

До дослідження включено хворих на автоімунний тиреоїдит (AIT) та гастроезофагеальну рефлюксну хворобу (ГЕРХ), що обумовлено декількома моментами: обидві патології часто виникають в молодому віці через значну поширеність вірусної інфекції в дитячих і підліткових колективах (як предиктор AIT) на тлі хронічних стресових ситуацій, які супроводжують навчання; нестабільністю нервової і ендокринної систем в період їх становлення; відсутністю правильних поведінкових i харчових звичок $[9,10,11]$.

Таким чином, метою нашої роботи було уточнення механізмів ендогенного контролю системи детоксикації ксенобіотиків у пацієнтів молодого віку з поєднаним перебігом ГЕРХ та AIT.

\section{МАТЕРІАЛИ ТА МЕТОДИ}

Обстежено 162 паціента з AIT, який у 120 випадках поєднувався з ГЕРХ (основна група). До групи порівняння увійшло 42 хворих з ізольованим АІT. Вік по групах склав $(21,9 \pm 2,7)$ та $(23,1 \pm 1,2)$ років відповідно. Контингент був представлений студентами різних вузів міста, що дозволило не тільки дотримати вікові межі, а й зіставити стресові, харчові та поведінкові навантаження. Контрольні показники отримані при обстеженні 20 практично здорових осіб аналогічного віку, статі та соціального статусу.

AIT було підтверджено наявністю антитіл до тиреопероксидази (АТ-ТПО) (норма до $34,0 \mathrm{MO} /$ мл), тиреоглобуліну (АТ-ТГ) (норма до $115 \mathrm{MO} / \mathrm{мл)} \mathrm{та} \mathrm{даних} \mathrm{ультразву-}$ кового дослідження (УЗД) щитовидної залози (ЩЗ). УЗД проводили за допомогою апарату Mindray DC-60 Exp, використову-

Таблиця 1

Структурні зміни паренхіми ЩЗ у обстежених хворих

\begin{tabular}{|c|c|c|c|c|c|}
\hline \multirow{2}{*}{ Структурні зміни паренхіми ЩЗ } & \multicolumn{2}{|c|}{$\begin{array}{l}\text { ГEPX + AIT } \\
\quad(n=120)\end{array}$} & \multicolumn{2}{|c|}{$\begin{array}{c}\mathrm{AIT} \\
(\mathrm{n}=42)\end{array}$} & \multirow{2}{*}{$\begin{array}{l}\text { Рівень } \\
\text { значущості }\end{array}$} \\
\hline & Абс. & $\%$ & Абс. & $\%$ & \\
\hline Дифрузні зміни & 67 & 55,8 & 20 & 47,6 & \multirow{3}{*}{$\begin{array}{l}\mathrm{df}=2 \\
\mathrm{c}\end{array}$} \\
\hline Дифрузно-вогнищеві зміни & 45 & 37,5 & 18 & 42,9 & \\
\hline $\begin{array}{c}\text { Дифрузні зміни у поєднанні з вузловими } \\
\text { утвореннями }\end{array}$ & 8 & 6,7 & 4 & 9,5 & \\
\hline
\end{tabular}

Примітка:

$\mathrm{p}<0,05$ - різниця є статистично достовірною між групами.

Таблиця 2

Показники тиреоїдного профілю у обстежених хворих

\begin{tabular}{c|c|c|c}
\hline Показник & $\begin{array}{c}\text { Контрольна група } \\
(\mathbf{n}=\mathbf{2 0})\end{array}$ & $\begin{array}{c}\text { ГEPX + AIT } \\
(\mathbf{n}=\mathbf{1 2 0})\end{array}$ & $\begin{array}{c}\text { AIT } \\
(\mathbf{n}=\mathbf{4 2})\end{array}$ \\
\hline АТ-ТПО, МО/мл & $26,8 \pm 5,1$ & $201,3 \pm 121,8^{*}$ & $188,4 \pm 92,2^{*}$ \\
\hline АТ-ТГ, МО/мл & $67,4 \pm 18,2$ & $303,3 \pm 112,8^{*}$ & $291,7 \pm 117,6^{*}$ \\
\hline ТТГ, мкМО/ мл & $1,7 \pm 0,6$ & $1,7 \pm 0,9$ & $1,8 \pm 1,1$ \\
\hline fТ3, пмоль/л & $4,3 \pm 0,4$ & $4,2 \pm 0,6$ & $3,9 \pm 0,5$ \\
\hline fТ4, пмоль/л & $13,9 \pm 2,2$ & $14,8 \pm 2,5$ & $15,4 \pm 2,6$ \\
\hline
\end{tabular}

Примітка:

* $\mathrm{p}<0,05$ - різниця є статистично достовірною між групами. 
вали В-режим із застосуванням доплерографічних методів: енергетичне та колірне доплерівське картування, імпульсно-хвильова доплерографія (табл. 1).

Функціональний стан ЩЗ оцінено на попередніх етапах дослідження імуноферментним методом в сироватці крові за показниками вмісту тиреотропного гормону (ТТГ) (норма 0,27-4,2 мкMО/мл), вільного трийодтироніну (fT3) (норма 2,5-5,8 пмоль/л) та тироксину (fT4) (норма 10,0-23,2 пмоль/л). Тиреоїдний профіль у обстежених хворих відповідав еутиреозу (табл. 2).

Діагноз ГЕРХ підтверджували характерними скаргами, даними анамнезу, клінічного та інструментального дослідження. Візуальну оцінку слизової оболонки стравоходу проводили при езофагогастродуоденоскопічному дослідженні (відеоендоскопічна система «Fuginon», Японія) з біопсією i подальшим гістологічним дослідженням матеріалу. Діагноз встановлювали згідно 3 рекомендаціями Монреальського консенсусу (2006 р.). У 34 випадках (28,3\%) встановили ерозивне ураження стравоходу та у $86(71,7 \%)$ неерозивне. Ступені ерозивної ГЕРХ визначали за Лос-Анджелеською класифрікацією (1994р.): ступінь А - 6 (17,7\%), ступінь В - 18 (52,9\%), ступінь С - 8 (23,5\%), ступінь D - 2 (5,9\%) хворих.

До роботи були залучені студенти, які підписали добровільну інформовану згоду на участь в дослідженні відповідно до положень Хельсенської Декларації Всесвітньої Медичної Асоціації (World Medical Associa- tion Declaration of Helsinki (2000 рік) і директив Європейського товариства 86/609 про участь людей в медико-біологічних дослідженнях.

Активність СОД2 (нг/мл) та рівня білка Клото (нг/мл) визначали в сироватці крові хворих імуноферментним методом, глутатіонредуктази (ГР) (МО/г Нв) та глутатіонпероксидази (ГПО) (мкмоль НАДФН/г Нв) досліджували спектрофотометричним методом в фрракції клітин. Використовували комерційні тест-системи фірми «Elabscience» (США).

Статистичну обробку даних проводили за допомогою пакета програм Statistica Basic Academic 13 for Windows En локальна. Закон розподілу всіх показників, що вивчалися, відрізнявся від нормального (критерій Колмогорова-Смирнова), тому для статистичної обробки даних використовували методи непараметричної статистики. Для перевірки залежності показників неперервної шкали від групи використовували непараметричні аналоги дисперсійного аналізу — критерій Краскела-Уолліса та медіанний тест. Для подальшого порівняння груп дослідження між собою та з групою контролю використовували критерій Манна-Уїтні. За текстом данні представляли у вигляді $\mathrm{M} \pm \mathrm{m}$, де $\mathrm{M}$ - середне вибіркове, $\mathrm{m}$ - стандартне відхилення. Для порівнянні частот зустрічальності ознаки використовували критерій «хі»-квадрат Пірсона. Статистично значущими вважали відмінності, які відповідали оцінці похибки ймовірності р < 0,05.

\section{РЕЗУЛЬТАТИ ТА ЇХ ОБГОВОРЕННЯ}

При вивченні властивостей глутатіонової фрракції АОС було встановлено, що рівень ГПО як у хворих на ізольований AIT, так і при його поєднанні з ГЕРХ достовірно знижувався. Аналогічна спрямованість була зафіксована при визначенні вмісту ГР (табл. 3).

Таким чином, глутатіонова ланка бере активну участь в роботі антиоксидантної системи, причому рівень захисту зміщуеться на її другу фазу.

Серед показників другої фрази детоксикації ксенобіотиків розглядають марганець-супероксиддисмутазу — мітохондрі- альний фермент, активність якого дозволяє «стримувати» накопичення токсичних радикалів. Так було встановлено достовірне підвищення рівня СОД2 порівняно з контрольною групою у пацієнтів, що були залучені до роботи (табл. 4).

Низкою авторів було показано, що підвищення активності СОД2 може виникати як в результаті безпосереднього включення системи АОЗ з метою контролю посиленого вироблення токсичних речовин, так і відбувається опосередковано - через активацію білка Клото [6, 7, 12, 13]. При визначенні рівню білка Клото у осіб з АІТ встановле- 
Показники глутатіонової ланки у обстежених

\begin{tabular}{c|c|c}
\hline Паціенти/показники & ГПО, МО/г Нв & ГР, мкмоль НАДФН/г Нв \\
\hline Контроль & $18,753(16,023 ; 19,8)$ & $1,875(1,845 ; 1,984)$ \\
\hline ГЕРХ + АIT & $13,32(11,1 ; 14,8)$ & $1,31(1,15 ; 1,367)$ \\
\hline AIT & $16,385(12,122 ; 17,98)$ & $1,674(1,6 ; 1,86)$ \\
\hline \multirow{2}{*}{ Достовірність між групами } & $\mathrm{U}_{1-2}=248, \mathrm{p}_{1-2}<0,01$ & $\mathrm{U}_{1-2}=0,00, \mathrm{p}_{1-2}<0,01$ \\
& $\mathrm{U}_{2-3}=531, \mathrm{p}_{2-3}<0,01$ & $\mathrm{U}_{2-3}=1479, \mathrm{p}_{2-3}<0,01$ \\
& $\mathrm{U}_{1-3}=851,5, \mathrm{p}_{1-3}<0,01$ & $\mathrm{U}_{1-3}=157, \mathrm{p}_{1-3}<0,01$ \\
\hline
\end{tabular}

Примітка:

$\mathrm{p}<0,05$ - різниця є статистично достовірною між групами;

U1-2, p1-2 - різниця між групою ГЕРX + AIT і контрольною групою;

U2-3, p2-3 - різниця між групою ГЕРX + AIT і ізольованою групою AIT;

U1-3, p1-3 - різниця між групою AIT і контрольною групою.

Активність марганець-супероксиддисмутази у обстежених хворих

\begin{tabular}{c|c|c|c}
\hline Групи хворих & $\begin{array}{c}\text { Активність СОД2, } \\
\text { нг/мл }\end{array}$ & $\begin{array}{c}\text { Достовірність } \\
\text { по відношенню } \\
\text { до контролю* }\end{array}$ & $\begin{array}{c}\text { Достовірність } \\
\text { між групами } \\
\text { ГЕРХ + АIT та АIT* }\end{array}$ \\
\hline ГЕРХ+АIT & $9,1965(7,248 ; 11,6385)$ & $\mathrm{U}=386, \mathrm{p}<0,01$ & $\mathrm{U}=2509,5, \mathrm{p}<0,01$ \\
\hline АIT & $7,5515(5,8327 ; 9,2338)$ & $\mathrm{U}=1273, \mathrm{p}<0,01$ & \\
\hline Контрольна & $4,472(3,701 ; 5,2325)$ & & \\
\hline
\end{tabular}

Примітка:

* $\mathrm{p}<0,05-$ різниця е статистично достовірною між групами.

Таблиця 5

Рівень білка Клото у групах хворих, що були обстежені

\begin{tabular}{c|c|c|c}
\hline Групи хворих & $\begin{array}{c}\text { Активність білка } \\
\text { Клото, нг/мл }\end{array}$ & $\begin{array}{c}\text { Достовірність } \\
\text { по відношенню } \\
\text { до контролю* }\end{array}$ & $\begin{array}{c}\text { Достовірність } \\
\text { між групами } \\
\text { ГЕРХ + АIT та АIT* }\end{array}$ \\
\hline ГЕРХ+AIT & $0,885(0,611 ; 1,184)$ & $\mathrm{U}=320,5, \mathrm{p}<0,01$ & $\mathrm{U}=1171, \mathrm{p}<0,01$ \\
\hline АIT & $0,5675(0,4398 ; 0,7324)$ & $\mathrm{U}=307, \mathrm{p}=0,08883$ & \\
\hline Контрольна & $0,4866(0,3679 ; 0,6098)$ & & \\
\hline
\end{tabular}

Примітка:

* $\mathrm{p}<0,05-$ різниця $є$ статистично достовірною між групами.

но його підвищення, але даний показник не мав достовірних відмінностей від контролю. При поєднанні ГЕРХ та АIT синтез білка перевищував контрольні величини майже в 2 рази (табл. 5).

Дослідження, присвячені вивченню стану AOC у хворих з коморбідністю ГЕРХ та AIT, у сучасній літературі відсутні. Однак $€$ дані стосовно окремих патогенетичних механізмів ураження стравоходу при тиреоїдній патології. Встановлено, що як гіпотак і гіпертиреоз можуть приводити до по- рушень моторики стравоходу, змін швидкості і амплітуди його перистальтики та тонусу нижнього езофрагеального сфінктера, що сприяє розвитку дисфрагії та формуванню редрюксу [14, 15, 16, 17]. За даними Chiu W.Y. та співавт., гіперфункція ЩЗ може викликати міопатію з ураженням поперечно-смугастих м'язів глотки і верхньої третини стравоходу [15]. У дослідженні Kaise M. та співавт. продемонстровано, що гіпертиреоз викликає гіпергастринемією, яка впливає на моторику шлунково-кишкового тракту [19]. 
Таким чином, наявність хронічних захворювань внутрішніх органів (ГЕРХ та AIT) у осіб молодого віку призводить до «прориву» першої лінії захисту АОС i, тим самим, посиленню контролю з боку другої фази системи. Дану обставину не можна пояснити тривалістю або агресивністю захворювань: ймовірно, такі зміни е результатом високої реактивності організму в осіб молодого віку. Цим можна пояснити і той факт, що на етапі спостереження хворих не відзначаеться тривалої активної стадії захворювань і формування ранніх ускладнень. У той же час AIT створюе несприятливий фон для подальшого перебігу за- хворювань: латентний перебіг запального процесу в ЩЗ призводить до постійного напруження АOC, тим самим забезпечуе їі виснаження. Тобто, обидві системи (запальна та оксидативна) «задіяні» в патогенезі ГЕРХ та AIT. В такому разі активний процес у стравоході через загальні системні механізми запалення та ендотеліальну дисфункцію судин призводить до прогресування AIT, ймовірним наслідком чого може бути формування гіпотиреозу i, можливо, ураження інших органів і систем, як через недостатній синтез тиреоїдних гормонів, так і патогенетичні складові ГЕРХ.

\section{ВИСНОВКИ}

1. Перебіг АIT та його поєднання з ГЕРХ призводить до активного залучення системи антиоксидантного захисту, що проявляється зниженням синтезу глутатіонредуктази та глутатіонпероксидази.

2. У хворих на AIT та коморбідністю AIT і ГЕРХ спостерігається збільшення вмісту мітохондріального ферменту СОД2 - показника другої фази системи детоксикації ксенобіотиків.

3. Коморбідний перебіг АIT та ГЕРХ призводить до стимуляції синтезу білка Клото, та тим самим, активації СОД2, що забезпечуе ендогенний контроль антиоксидантного захисту.

\section{ЛITEPATУPA \\ (REFERENCES)}

1. Dovhanj J, Švagelj D. Oxidative Stress Pathway Driven by Inflammation in Gastric Mucosa. Gastritis and Gastric Cancer. New Insights in Gastroprotection, Diagnosis and Treatments, Paola Tonino, IntechOpen, 2011: $296 \mathrm{p}$.

2. Čolak E, Ignjatović S, Radosavljević A, Žorić L. J Clin Biochem Nutr 2017; 60(2): 100-107.

3. Espinosa-Diez C, Miguel V, Mennerich D, et al. Redox Biol 2015; 6: 183-197.

4. Sznarkowska A, Kostecka A, Meller K, Bielawski KP. Oncotarget 2017; 8(9): 15996-16016.

5. Kahl R, Kampkötter A, Wätjen W, Chovolou Y. Drug Metab Rev 2004; 36(3-4): 747-762.

6. Younus H. Int J Health Sci (Qassim) 2018; 12(3): 88-93.

7. Ighodaro OM, Akinloye OA. Alexandria J Med 2018; 54(4): 287-293

8. Lim SW, Jin L, Luo K, et al. Cell Death Dis 2017; 8(8): e2972.

9. lrashed AA, Aljammaz KI, Pathan A, et al. J Family Med Prim Care 2019; 8(2): 462-467.
10. Sharma A, Sharma PK, Puri P. Med J Armed Forces India 2018; 74: 250-254.

11. Bliddal S, Nielsen CH, Feldt-Rasmussen U. F1000Res 2017; 6: 1776 .

12. Fukai T, Ushio-Fukai M. Antioxid Redox Signal 2011; 15(6): 1583-1606.

13. Rakugi H, et al. Endocrine 2007; 31: 82-87.

14. Noto H, Mitsuhashi T, Ishibashi S, Kimura S. Intern Med 2000; 39: 472-473.

15. Chiu WY, Yang CC, Huang IC, Huang TS. Dysphagia 2004; 19: 120-124.

16. Branski D, Levy J, Globus M, et al. J Clin Gastroenterol 1984; 6: 437-440.

17. Wright RA, Penner DB. Dig Dis Sci 1981; 26: 376-377.

18. Savina LV, Semenikhina TM, Korochanskaia NV, et al. Klin Med (Mosk) 2006; 84: 71-74.

19. Kaise M, Sumitomo H, Hashimoto K, et al. Nippon Shokakibyo Gakkai Zasshi 1992; 89: 1990-1995. 


\title{
ФАКТОРИ ПРОГРЕСУВАННЯ АВТОІМУННОГО ТИРЕОЇДИТУ У ОСІБ МОЛОДОГО ВІКУ З ГАСТРОЕЗОФАГЕАЛЬНОЮ РЕФЛЮКСНОЮ ХВОРОБОЮ: РОЛЬ СИСТЕМИ ДЕТОКСИКАЦІЇ КСЕНОБІОТИКІВ, МЕХАНІЗМІВ ЕНДОГЕННОГО КОНТРОЛЮ ТА СТИМУЛЯЦІІ
}

\author{
Пасієшвілі Т. М., Ковальова О. М., Пасієшвілі Л. М., Железнякова Н. М.
}

Харківський національний медичний університет, м. Харків, Украӥна pasotoma2017@gmail.com

До дослідження залучено хворих на автоімунний тиреоїдит та гастроезофагеальну рефлюксну хворобу, що обумовлено частим виникненням даних нозологій в молодому віці. Метою дослідження було уточнення механізмів ендогенного контролю системи детоксикації ксенобіотиків у пацієнтів молодого віку з поєднаним перебігом автоімунного тиреоїдиту та гастроезофагеальної рефлюксної хвороби. До роботи було залучено 162 хворих на автоімунний тиреоїдит, який у 120 випадках поеднувався з гастроезофагеальною рефлюксною хворобою. Контингент досліджених склали студенти вузів міста віком від 18 до 25 років. Автоімунний тиреоїдит було підтверджено наявністю антитіл до тиреопероксидази, тиреоглобуліну та даних ультразвукового дослідження щитовидної залози. Функціональний стан щитовидної залози оцінювали за вмістом тиреотропного гормону, вільного трийодтироніну та вільного тироксину. Тиреоїдний профріль у обстежених хворих відповідав еутиреозу. Діагноз гастроезофагеальної рефлюксної хвороби підтверджували характерними скаргами, даними анамнезу, клінічного та інструментального дослідження. Вивчали показники другої фази антиоксидантної системи - глутатіонпероксидазу, глутатіонредуктазу, маргенець-супероксиддисмутазу, а також білок Клото. Отримані результати було оброблено із застосуванням ліцензійної програми Statistica Basic Academic 13 for Windows. Встановлено, що перебіг автоімунного тиреоїдиту та його поєднання 3 гастроезофагеальною рефлюксною хворобою призводить до активного залучення системи антиоксидантного захисту, що проявлялося зниженням синтезу глутатіонредуктази та глутатіонпероксидази. Одночасно визначенно достовірне збільшення синтезу мітохондріальної маргенець-супероксиддисмутази - показника другої фрази системи детоксикації ксенобіотиків. Вміст білка Клото у хворих на автоімунний тиреоїдит мав тенденцію до збільшення та вірогідно підвищувався при коморбідності. Таким чином, сукупний перебіг автоімунного тиреоїдиту та гастроезофагеальної рефлюксної хвороби супроводжуеться залученням показників другої фази антиоксидантної системи, що дозволяе контролювати утворення токсичних речовин. Та одночасна стимуляція маргенець-супероксиддисмутази і білка Клото сприяе ендогенному контролю антиоксидантного захисту.

Ключові слова: автоімунний тиреоїдит, гастроезофагеальна рефлюксна хвороба, антиоксидантна система, білок Клото.

\section{PROGRESSION FACTORS OF AUTOIMMUNE THYROIDITIS IN YOUNG PEOPLE WITH GASTROESOPHAGEAL REFLUX DISEASE: THE ROLE OF THE XENOBIOTIC DETOXIFICATION SYSTEM, MECHANISMS OF ENDOGENOUS CONTROL AND STIMULATION}

Pasiieshvili T. M., Kovaloyva O. M., Pasiieshvili L. M., Zhelezniakova N. M.

\section{Kharkiv National Medical University, Kharkiv, Ukraine} pasotoma2017@gmail.com

The study involved patients with autoimmune thyroiditis and gastroesophageal reflux disease, which is due to the frequent occurrence of these nosologies at a young age. Purpose of the study was to clarify the mechanisms of endogenous control of the xenobiotic detoxification system in young patients with autoimmune thyroiditis and gastroesophageal reflux disease. The work involved 162 patients with autoimmune thyroiditis, which in 120 cases was combined with gastroesophageal reflux disease. The contingent of the surveyed was represented by students of the city's universities aged 18 to 25 . Autoimmune thyroiditis was confirmed by the presence of antibodies to thyroperoxidase and thyroglobulin and by ultrasound of the thyroid gland. The functional state of the thyroid gland was assessed by the content of thyroid-stimulating hormone, free triiodothyronine and free thyroxine. The thyroid profile in the examined patients corresponded to euthyroidism. The diagnosis of gastroesophageal reflux disease was confirmed by tipical complaints, data from anamnesis, clinical and instrumental studies.The indicators of the second phase of the antioxidant system - glutathione peroxidase, glutathione reductase, manganese superoxide dismutase, and also the Klotho protein were studied. Licensed program Statistica Basic Academic 13 for Windows was used. It was found that the course of autoimmune thyroiditis and its combination with gastroesophageal reflux disease leads to the activation of the antioxidant defense system, which was manifested by a decrease in the synthesis of glutathione reductase and glutathione peroxidase. At the same time, a significant increase in the synthesis of the mitochondrial manganese superoxide dismutase, an indicator of the second phase of the xenobiotic detoxification system, was proved. The content of Klotho protein in patients with autoimmune thyroiditis had a tendency to increase and significantly increased in the case of comorbidity. Thus, the combined course of autoimmune thyroiditis and gastroesophageal reflux disease is accompanied by the inclusion of indicators of the second phase of the antioxidant system, which makes it possible to control the formation of toxic substances, and the simultaneous stimulation of manganese superoxide dismutase and Klotho protein provides endogenous control of antioxidant protection.

Key words: autoimmune thyroiditis, gastroesophageal reflux disease, antioxidant system, Klotho protein. 